\title{
Morphology and density of mussels on natural and aquaculture structure habitats: implications for sea duck predators
}

\author{
Molly Kirk ${ }^{1, *}$, Daniel Esler ${ }^{2}$, W. Sean Boyd ${ }^{3}$ \\ ${ }^{1}$ Centre for Wildlife Ecology, Simon Fraser University, 8888 University Drive, Burnaby, British Columbia V5A 1S6, Canada \\ ${ }^{2}$ Centre for Wildlife Ecology, Simon Fraser University, 5421 Robertson Road, Delta, British Columbia V4K 3N2, Canada \\ ${ }^{3}$ Canadian Wildlife Service, Environment Canada, 5421 Robertson Road, Delta, British Columbia V4K 3N2, Canada
}

\begin{abstract}
We compared density and morphology of wild mussels Mytilus trossulus growing naturally on shellfish farming structures to that of mussels from nearby intertidal areas, and considered the relevance to molluscivorous sea ducks. Mussel density on aquaculture structures greatly exceeded that of intertidal areas and farm mussels were larger, had lower shell mass, and had weaker byssal attachments. Differences in environmental conditions and predation regimes throughout the summer growing season were likely responsible for these differences. These morphological and density differences, in turn, have important implications for their primary winter predators, sea ducks, including surf scoters Melanitta perspicillata and Barrow's goldeneyes Bucephala islandica. Higher levels of mussel depletion in farm habitats and strong associations of ducks with shellfish farms indicate that sea ducks responded to this novel, profitable prey resource. Our results support recent research that indicates that artificial structures introduced into coastal areas create novel marine habitats that can support unique communities of epibiota. That sea ducks appear to profit from the introduction of aquaculture structures is evidence of a positive effect of anthropogenic modifications in a coastal environment.
\end{abstract}

KEY WORDS: Mytilus trossulus $\cdot$ Mussels $\cdot$ Shellfish aquaculture $\cdot$ Epibiotic growth $\cdot$ Anthropogenic structures $\cdot$ Sea ducks

Resale or republication not permitted without written consent of the publisher

\section{INTRODUCTION}

Development and urbanisation of coastal areas have altered marine habitats and communities across the globe. Anthropogenic changes include the introduction of artificial structures such as breakwaters, bridges, pontoons, wharfs, and buoys, which create novel marine habitats where the assemblages of epibiota are not equivalent to natural rocky shore communities (Connell 2001). This type of habitat introduction and the subsequent changes to community structure constitute significant alterations to the marine environment, with potential direct and indirect trophic web effects in local ecosystems (Glasby \& Connell 1999).
One current change to coastal habitats in British Columbia is the expansion of the shellfish aquaculture industry. Shellfish farming involves introducing structures into coastal waters such as floating rafts, buoys and lines, all of which serve as a novel recruitment surface for wild bay mussel Mytilus trossulus spat. The effects of the shellfish aquaculture industry on natural marine communities have only recently been studied (Stenton-Dozey et al. 2001, Lasiak et al. 2006), and trophic consequences resulting from epifaunal growth on shellfish aquaculture structures have not previously been considered. In this study, we investigated differences in density and morphology between mussels growing on shellfish aquaculture structures and those 
in natural intertidal beds, and considered implications for major mussel consumers, sea ducks.

The abundance of Mytilus spp. on floating artificial structures can be significantly higher than on natural reefs (Connell 2001, Glasby \& Connell 2001, Holloway \& Connell 2002). Conventional rocky intertidal community ecology suggests that adult Mytilus distribution and abundance are controlled primarily by the foraging activity of predatory sea stars Pisaster spp. (Menge et al.1994). Anthropogenic structures may act as refugia from invertebrate predators such as sea stars and crabs, which are generally excluded from suspended lines and rafts. Alternatively, larval settlement of mussels can be enhanced on floating structures relative to intertidal areas due to abiotic conditions such as water flushing regimes, depth or light (Holloway \& Connell 2002).

Environmental conditions and predation regimes can also cause variation in the growth and morphology of mussels (Seed \& Suchanek 1992). Conditions of rocky intertidal habitats generally include periodic exposure to desiccation, extreme temperatures, and wave exposure. In many molluscs, including mussels, these conditions can lead to shell thickening in higher intertidal zones (Beadman et al. 2003) or in areas of heavy wave activity (Akester \& Martel 2000). Conversely, subtidal mussels not only grow faster than airexposed intertidal mussels, but also develop thinner shells (Seed 1968). Morphology can also vary with predation risk (Reimer \& Tedengren 1996). The presence of predators (crabs and sea stars) and shells of crushed conspecifics can cause shell thickening in molluscs (Reimer \& Tedengren 1996, Leonard et al. 1999). Thicker shelled bivalves may invest more energy into shell development, thus reducing flesh content (GossCustard et al. 1993). Byssal thread strength is also positively related to wave exposure or water velocity (Harger 1970), but can also increase in response to predation (Leonard et al. 1999).

The attributes of prey can strongly affect the behaviours and fitness of predators. Variation in prey abundance influences habitat choice by predators, including sea ducks (Guillemette et al. 1996, Larsen \& Guillemette 2000, Žydelis et al. 2006). Prey selection may also be influenced by the size and morphology of prey items. Growth rates, byssal strength, and shell shape or thickness of mussels can affect predation attempts and success by crabs and sea stars (Norberg \& Tedengren 1995, Reimer \& Tedengren 1996), or diving ducks (De Leeuw 1999) Molluscivorous sea ducks will often attempt to reduce shell intake by selecting smaller or thinner-shelled bivalves (Bustnes \& Erikstad 1990). Shell-crushing resistance is also an important determinant of the foraging value of a prey type to diving ducks (Richman \& Lovvorn 2003). If variation in prey quality affects habitat use patterns of predators, this may lead to variable prey depletion by habitat. There is a growing appreciation that sea ducks can have significant, top-down depletion effects on bivalves over winter (Guillemette et al. 1996, Larsen \& Guillemette 2000, Lewis et al. 2007), which in turn might lead to temporal changes in availability of prey in preferred foraging habitats.

The objective of this study was to evaluate variation in the mussel prey of 2 sea ducks, surf scoters Melanitta perspicillata and Barrow's goldeneyes Bucephala islandica, that winter in the heterogeneous and humanmodified landscape of Malaspina Inlet $\left(50.0^{\circ} \mathrm{N}\right.$, $124.7^{\circ} \mathrm{W}$ ) in the Strait of Georgia, British Columbia, Canada. This area is a series of fjords that are used extensively by a deep-water oyster aquaculture industry. The natural shoreline consists of rocky slopes and littoral reefs where mussels grow intertidally. Sea duck numbers here vary annually, ranging from 600 to over 3000 surf scoters and 200 to 1800 Barrow's goldeneyes in the winter. Both these sea ducks feed by diving in the intertidal or shallow subtidal zones and mussels are their principal prey in rocky habitats. We investigated differences in density, size and morphological attributes of mussels at floating shellfish aquaculture structures and intertidal shores and reefs, to determine if differences existed that may affect foraging preferences of wintering sea ducks.

\section{MATERIALS AND METHODS}

Mussel density. We sampled mussels in intertidal and shellfish aquaculture structure (herein called 'farm') habitats of Malaspina Inlet. Bay mussels Mytilus trossulus dominate the protected waters of the Strait of Georgia and are part of the M. edulis complex that includes M. edulis and M. galloprovincialis; these species are visually indistinguishable but genetically distinct (McDonald et al. 1991). Hybridization of the 3 Mytilus species does occur in the North Pacific (Suchanek et al. 1997) during broadcast spawning events, but $M$. edulis and M. galloprovincialis are considered relatively rare north of California (Suchanek et al. 1997) and we assumed that the mussels in our samples were all a single species, presumably $M$. trossulus. The oyster farms consist of rafts, buoys and associated lines where wild mussel spat settles each spring. Because space is a limiting factor for mussel settlers (Seed \& Suchanek 1992), we report an estimate of space availability in each mussel habitat in the study area. The first set of mussel density data was collected in the fall, prior to sea duck arrival (September and October 2004). The second phase of sampling occurred in early spring (March and April 2005) after most sea ducks had left the study area, allowing assessment of 
temporal changes in mussel density during the period when ducks were present.

An extensive survey of randomly selected transects quantified mussel distribution and density in intertidal habitats throughout the study area. The shoreline of the Malaspina Inlet study area was divided into 34 units with an average length of $2.3 \mathrm{~km}$ ( $\pm 0.2 \mathrm{SE})$. Shoreline units were digitized for each unit in ArcView (ESRI). Using the Random Point Generator ArcView extension, 2 points were randomly selected in each shoreline unit as start points for transects (for a total of 68 transects). Each $100 \mathrm{~m}$ transect ran parallel to shore and fell within the mid-tidal range (between 1.5 and $4.5 \mathrm{~m}$ above chart datum) to reflect mussel habitat. Along each transect, 10 quadrats $(1 \times 1 \mathrm{~m})$ were placed at every tenth meter and percent cover of mussels was estimated. Within each large quadrat where mussels occurred, a subsample quadrat $(0.1 \times 0.1 \mathrm{~m})$ was tossed haphazardly into the larger quadrat and mussels within the subsample quadrat were counted and measured to $5 \mathrm{~mm}$ length classes. The total extent of surface area in the intertidal sites was estimated to be $1.5 \mathrm{~km}^{2}$ based on digitized nautical charts with height above datum indicated. Because the occurrence of mussels was very rare in these transects, 5 specific sites were selected for intensive sampling for density and length of mussels. These 5 intertidal sites represent known mussel beds that had significant sea duck use in 2 previous years of research. At each site, 3 transects were placed parallel to each other, evenly spaced along the site's mussel habitat ( 1.5 to $4.5 \mathrm{~m}$ above chart datum). On each transect, 10 quadrats $(0.1 \times 0.1 \mathrm{~m})$ were sampled at regular intervals from a randomly selected start point. In each quadrat, all mussels were counted and measured to $5 \mathrm{~mm}$ length classes, and a total of 30 quadrats were sampled per intertidal site. The total surface area of the intensively sampled reefs consisted of an estimated $3400 \mathrm{~m}^{2}$.

At 10 oyster farms, the density and length of mussels on aquaculture structures were measured through systematic random sampling. The farms were selected to cover the geographic breadth of the study area and to include farms of varying size and type (i.e. those using rafts vs. buoys). Within each farm, oyster-culture structures were consecutively numbered and a sample taken at every nth structure (with $\mathrm{n}$ calculated as the total number of structures available divided by 30), beginning at a randomly chosen start point, resulting in a sample size of 30 distributed evenly through each farm. We sampled a standard square area on each structure $(0.1 \times 0.1 \mathrm{~m})$. Mussels were removed from the sample area, counted, and measured to $5 \mathrm{~mm}$ length classes. Total available surface area of all farming structures in the study area was an estimated $5200 \mathrm{~m}^{2}$.
Mussel morphology. Mussel morphology characteristics were measured in the fall and early winter, after approximately 6 mo of summer growth and prior to the arrival of the majority of sea ducks to the study area. We measured mussel byssal strength at both farms and intertidal sites. A spring scale was attached to the selected mussel by an alligator clip or rope tether and pulled until the byssal threads tore and the mussel was removed from the substrate (Harger 1970). The weight recorded by the spring scale was converted into Newtons $(1 \mathrm{~kg}=9.81 \mathrm{~N})$. The removed mussels were measured to $5 \mathrm{~mm}$ length classes ranging from 15 to $50 \mathrm{~mm}$. Ten mussels from each length class in each habitat type were tested ( $\mathrm{n}=70$ per habitat).

We quantified mussel shell-crushing resistance using an improvised tensometer. It measured the force required to crack shells of mussels from farm and intertidal habitats (Hamilton et al. 1999, Richman \& Lovvorn 2003). We measured length of each mussel ( $\pm 1 \mathrm{~mm})$. A C-clamp attached to a digital scale was manually tightened down onto the mussel, until the shell first cracked, at which point the weight registered on the digital scale was recorded in $\mathrm{kg}$ and converted to N. For each habitat and $5 \mathrm{~mm}$ length class, we crushed approximately 10 mussels ( $\mathrm{n}=212$ farm mussels, $\mathrm{n}=178$ intertidal mussels).

Fresh wet weight and dry mass of the shell and flesh components of mussels ( $\mathrm{n}=230$ from farms and $\mathrm{n}=175$ from intertidal habitats) were measured in the laboratory, and recorded by shell length $( \pm 0.1 \mathrm{~mm})$. A subset of mussels ( $\mathrm{n}=105$ from farms and $\mathrm{n}=98$ from intertidal habitats) was processed for energy density using a bomb calorimeter (Parr Instrument). Because the dried mass of mussels smaller than $20 \mathrm{~mm}$ was too small to be processed singly, these length classes were combined and burned in the calorimeter in groups of 2 to 10 individual mussels. All dried mussel tissue specimens were burned in the oxygen bomb and the heat of combustion was measured in the calorimeter and converted into $\mathrm{kJ} \mathrm{g}^{-1}$.

\section{DATA ANALYSES}

We used general linear models generated in Program SAS to assess variation in mussel density and morphological characteristics. An information theoretic approach was used in model selection (Burnham \& Anderson 2002). For all models considered, we calculated Akaike's Information Criterion corrected for small sample size $\left(\mathrm{AIC}_{\mathrm{c}}\right)$, which indicates the degree of parsimony of a model, balancing explanatory value against overfitting, relative to all other models in a candidate set. We also compared the $\mathrm{AIC}_{\mathrm{c}}$ value for each model to that of the best-supported model $\left(\Delta \mathrm{AIC}_{\mathrm{C}}\right)$ to 
assess the relative support for each candidate model. $\mathrm{AIC}_{\mathrm{C}}$ weights $\left(\mathrm{AIC}_{\mathrm{C}} \mathrm{W}\right)$ also were calculated, to express the likelihood that a certain model is the best model given the data and candidate model set.

\section{Mussel density}

The candidate set of general linear models used to determine sources of variation in mussel density (number per $100 \mathrm{~cm}^{2}$ ) included the following: habitat (farm or intertidal) singly, season (fall or spring) singly, habitat and season additively, habitat and season interactively both with and without main effects, and a null, or equal means, model. To determine whether mean mussel length differed between habitats, we calculated mean mussel length $( \pm \mathrm{SE})$ by habitat type (farm and intertidal) and conducted an analysis in which 2 candidate models were contrasted: a model with a habitat variable and an equal means model, which is roughly analogous to a $t$-test under a hypothesis testing paradigm. We assigned the mid-point of each $5 \mathrm{~mm}$ length class as the absolute length in the mean mussel length calculations.

\section{Mussel morphology}

We used the same candidate set of general linear models to assess variation in the following response variables: byssal thread strength $(\mathrm{N})$, shell-crushing force $(\mathrm{N})$, shell-free dry mass $(\mathrm{g})$, shell mass $(\mathrm{g})$, tissue to shell mass ratio, energy density $\left(\mathrm{kJ} \mathrm{g}^{-1}\right)$, and total energy per individual mussel $(\mathrm{kJ})$. The 10 candidate models considered were: (1) length, (2) length + length $^{2}$, (3) habitat, (4) length + habitat (5) length + length ${ }^{2}+$ habitat, (6) length + length $^{2}+$ habitat + habitat $\times$ length $^{2}$, (7) length + length $^{2}+$ habitat $\times$ length $^{2}$, (8) length + habitat + habitat $\times$ length, (9) length + habitat $\times$ length and (10) a null or equal means model. This set of candidate models allowed us to determine whether mussel morphological characteristics varied by length, either linearly or non-linearly, and also whether these relationships varied by habitat.

\section{RESULTS}

\section{Mussel density}

We found that mussel density varied strongly by habitat and by season (Fig. 1). Within the intertidal study area, the vast majority of shoreline was devoid of mussels. In the extensive transects, mussels covered an average of $0.2( \pm 0.07)$ percent of the intertidal area and

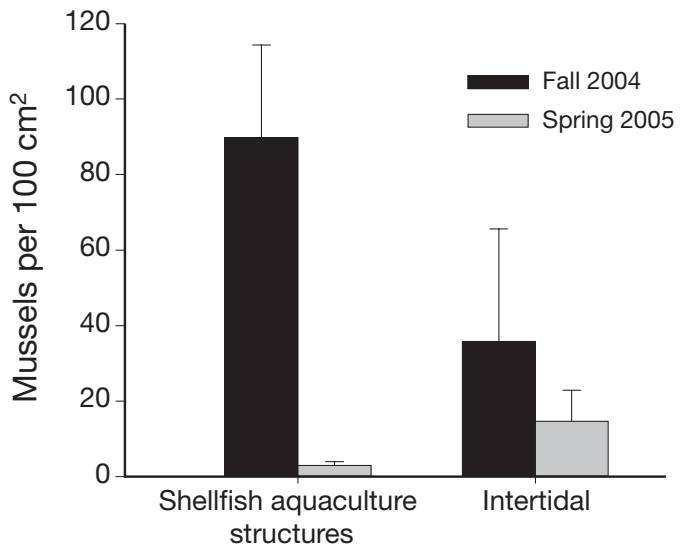

Fig. 1. Mytilus trossulus. Mean mussel density (mean $\pm 95 \%$ CI) by habitat (aquaculture structure or intertidal) and season (fall 2004 or spring 2005) in Malaspina Inlet, British Columbia, 2004-2005

mean density of mussels was very low $(0.8 \pm 0.4 \mathrm{SE}$ mussels per $100 \mathrm{~cm}^{2}$ ). These data were excluded from any further analyses and the remaining results include only intensive samples. Within the candidate model set, the habitat-season interaction model best explained variation in mussel density $\left(\mathrm{AIC}_{\mathrm{C}} \mathrm{W}=0.88, \mathrm{r}^{2}=0.27\right.$, Table 1), with no other model receiving significant support. This indicated that mussel densities differed between farm and intertidal habitats and the seasonal change in density also differed by habitat. Specifically, mussel densities at farms were dramatically higher than intertidal areas in the fall, but lower in the spring (Fig. 1). The intensively sampled intertidal sites had much lower fall densities $(36 \pm 9 \mathrm{SE}$ mussels per $\left.100 \mathrm{~cm}^{2}\right)$ than farms $\left(90 \pm 10 \mathrm{SE}\right.$ mussels per $\left.100 \mathrm{~cm}^{2}\right)$. Depletion of mussels, almost certainly the result of sea duck predation, was very dramatic in farms as spring densities were reduced by $97 \%$ to just $3 \pm 0.4 \mathrm{SE}$ mussels per $100 \mathrm{~cm}^{2}$. In contrast, intertidal densities only declined by $61 \%$ to $14 \pm 2 \mathrm{SE}$ mussels per $100 \mathrm{~cm}^{2}$.

Mussels on farms were larger than in the intertidal habitats. Average mussel length was $24.2 \mathrm{~mm}( \pm 0.8 \mathrm{SE})$ in farm habitats and $17.1 \mathrm{~mm}( \pm 1.4 \mathrm{SE})$ in intertidal areas (Fig. 2), and the model with habitat as an explanatory variable was strongly supported $\left(\mathrm{AIC}_{\mathrm{C}} \mathrm{W}=1.00\right)$ relative to the null model $\left(\mathrm{AIC}_{\mathrm{C}} \mathrm{W}=0.00\right)$. We believe that the mussels we sampled were largely the result of a single set the previous spring and that observed differences in length between habitats were due to differences in growth rates. Mussels from an artificial wharf first placed in the water in March 2004, yielded a length class distribution very similar to that on farms by October 2004 . This suggests they attained their length in approximately 6 mo of growth. The smaller average length in the intertidal habitat implies that mussels grow more slowly in areas with natural tidal fluctuations (Seed 1968). 
Table 1. Mytilus sp. Model selection results from the general linear model assessment of variation in mussel density by habitat (farm or intertidal) and season (fall or spring) in Malaspina Inlet, British Columbia, 2004-2005. The number of parameters includes +1 parameter for an intercept and +1 parameter for a variance estimate. Models are listed by the change in Akaike's Information Criterion corrected for small sample size $\left(\Delta \mathrm{AIC}_{\mathrm{c}}\right)$

\begin{tabular}{|llcrrr|}
\hline $\begin{array}{l}\text { Response } \\
\text { variable }\end{array}$ & Model & $\begin{array}{c}\text { Number of } \\
\text { parameters }\end{array}$ & \multicolumn{2}{c}{$\begin{array}{c}\mathrm{AIC}_{\mathrm{c}} \\
\text { weight }\end{array}$} & $\mathrm{r}^{2}$ \\
\hline Mussel density & Habitat $\times$ season & 6 & 0.00 & 0.88 & 0.27 \\
& Habitat + habitat $\times$ season & 8 & 4.04 & 0.12 & 0.27 \\
& Habitat + season & 6 & 46.25 & 0.00 & 0.24 \\
& Season & 4 & 60.69 & 0.00 & 0.23 \\
& Habitat & 4 & 427.71 & 0.00 & 0.01 \\
& Null & 2 & 433.62 & 0.00 & 0.00 \\
\hline
\end{tabular}

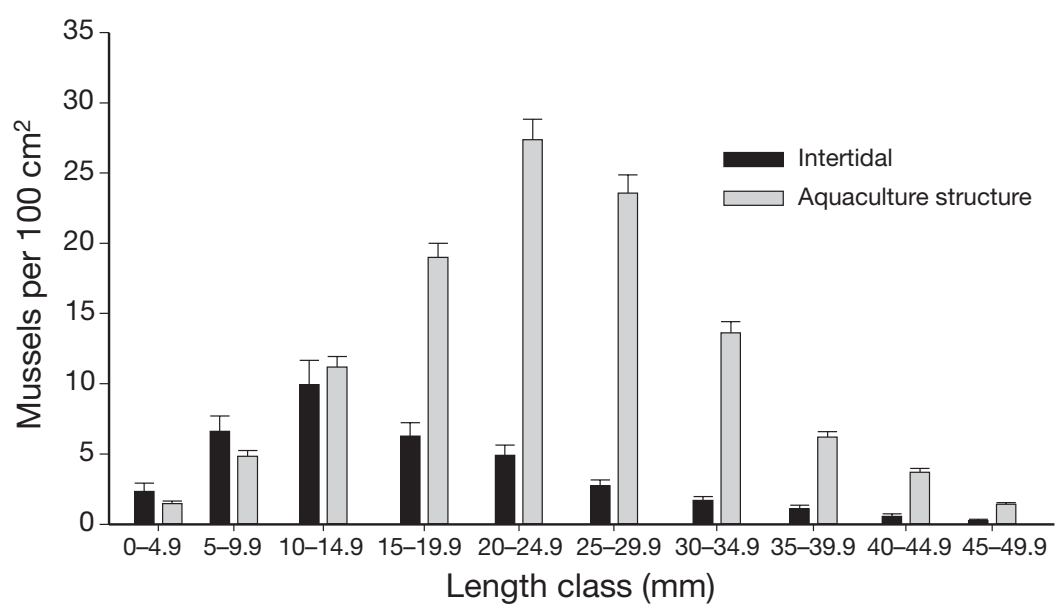

Fig. 2. Mytilus trossulus. Mussel densities (mean $\pm \mathrm{SE}$ ) by length class in intertidal and shellfish aquaculture habitats in Malaspina Inlet, British Columbia, fall 2004

\section{Mussel morphology}

Length and habitat were important in explaining variation in all attributes of mussel morphology, excluding energy density (Table 2, Fig. 3).

Variation in byssal strength was best explained by both length and habitat. The most parsimonious model included length and a length-habitat interaction $\left(\mathrm{AIC}_{\mathrm{C}} \mathrm{W}=0.53, \mathrm{r}^{2}=0.40\right)$ while the second ranked model, which included the length squared variable, also received a moderate amount of support $\left(\mathrm{AIC}_{\mathrm{C}} \mathrm{W}=\right.$ $0.28, r^{2}=0.40$ ) (Table 2). Byssal strength increased linearly with length and intertidal mussels had stronger byssal threads in all length classes, increasing more steeply with length than mussels from farms (Fig. 3A).

Shell-crushing force increased exponentially with length for both habitats but increased at a higher rate for intertidal mussels than mussels growing in farm environments (Fig. 3B). The model best supported by the data (Table 2) included length, length squared and a habitat-length squared interaction $\left(\mathrm{AIC}_{\mathrm{C}} \mathrm{W}=0.85, \mathrm{r}^{2}=0.65\right)$. In general, more force was required to crush the shells of intertidal mussels than those from farms. A similar pattern was found with shell mass. The most parsimonious

Table 2. Mytilus sp. Summary of model selection results for variation in mussel morphology in 2 habitats (farm and intertidal) in Malaspina Inlet, British Columbia, 2004. The number of parameters includes +1 parameter for an intercept and +1 parameter for a variance estimate. Each model set presents only those models with $\mathrm{AIC}_{\mathrm{c}}$ weights greater than 0.10 , in order of $\Delta \mathrm{AIC} \mathrm{C}_{\mathrm{C}}$

\begin{tabular}{|c|c|c|c|c|c|}
\hline Response variable & Model & $\begin{array}{l}\text { Number of } \\
\text { parameters }\end{array}$ & $\Delta \mathrm{AIC}_{\mathrm{c}}$ & $\begin{array}{c}\mathrm{AIC}_{\mathrm{c}} \\
\text { weight }\end{array}$ & $\mathrm{r}^{2}$ \\
\hline \multirow[t]{3}{*}{ Byssal strength } & Length + habitat $\times$ length & 4 & 0.00 & 0.43 & 0.40 \\
\hline & Length + length $^{2}+$ habitat $\times$ length $^{2}$ & 5 & 1.27 & 0.23 & 0.40 \\
\hline & Length + habitat + habitat $\times$ length & 5 & 1.87 & 0.17 & 0.40 \\
\hline \multirow[t]{2}{*}{ Crushing force } & Length + length ${ }^{2}+$ habitat $\times$ length ${ }^{2}$ & 5 & 0.00 & 0.67 & 0.65 \\
\hline & Length + length $^{2}+$ habitat + habitat $\times$ length $^{2}$ & 6 & 1.41 & 0.33 & 0.65 \\
\hline \multirow[t]{2}{*}{ Shell mass } & Length + length $^{2}+$ habitat + habitat $\times$ length $^{2}$ & 6 & 0.00 & 0.69 & 0.92 \\
\hline & Length + length $^{2}+$ habitat $\times$ length ${ }^{2}$ & 5 & 1.56 & 0.31 & 0.92 \\
\hline \multirow[t]{2}{*}{ Shell-free dry mass } & Length + length $^{2}+$ habitat $\times$ length $^{2}$ & 5 & 0.00 & 0.68 & 0.79 \\
\hline & Length + length $^{2}+$ habitat + habitat $\times$ length $^{2}$ & 6 & 1.53 & 0.32 & 0.79 \\
\hline Tissue:shell ratio & Length + length $^{2}+$ habitat + habitat $\times$ length $^{2}$ & 6 & 0.00 & 0.94 & 0.27 \\
\hline \multirow[t]{3}{*}{ Energy density } & Null & 2 & 0.00 & 0.30 & 0.00 \\
\hline & Length + habitat + length $\times$ habitat & 5 & 1.64 & 0.13 & 0.10 \\
\hline & Length + length ${ }^{2}$ & 4 & 2.08 & 0.11 & 0.05 \\
\hline \multirow[t]{3}{*}{ Energy ind..$^{-1}$} & Length + length $^{2}+$ habitat + habitat $\times$ length $^{2}$ & 6 & 0.00 & 0.57 & 0.85 \\
\hline & Length + length $^{2}+$ habitat & 5 & 1.09 & 0.33 & 0.85 \\
\hline & Length + length ${ }^{2}$ & 4 & 4.21 & 0.12 & 0.84 \\
\hline
\end{tabular}



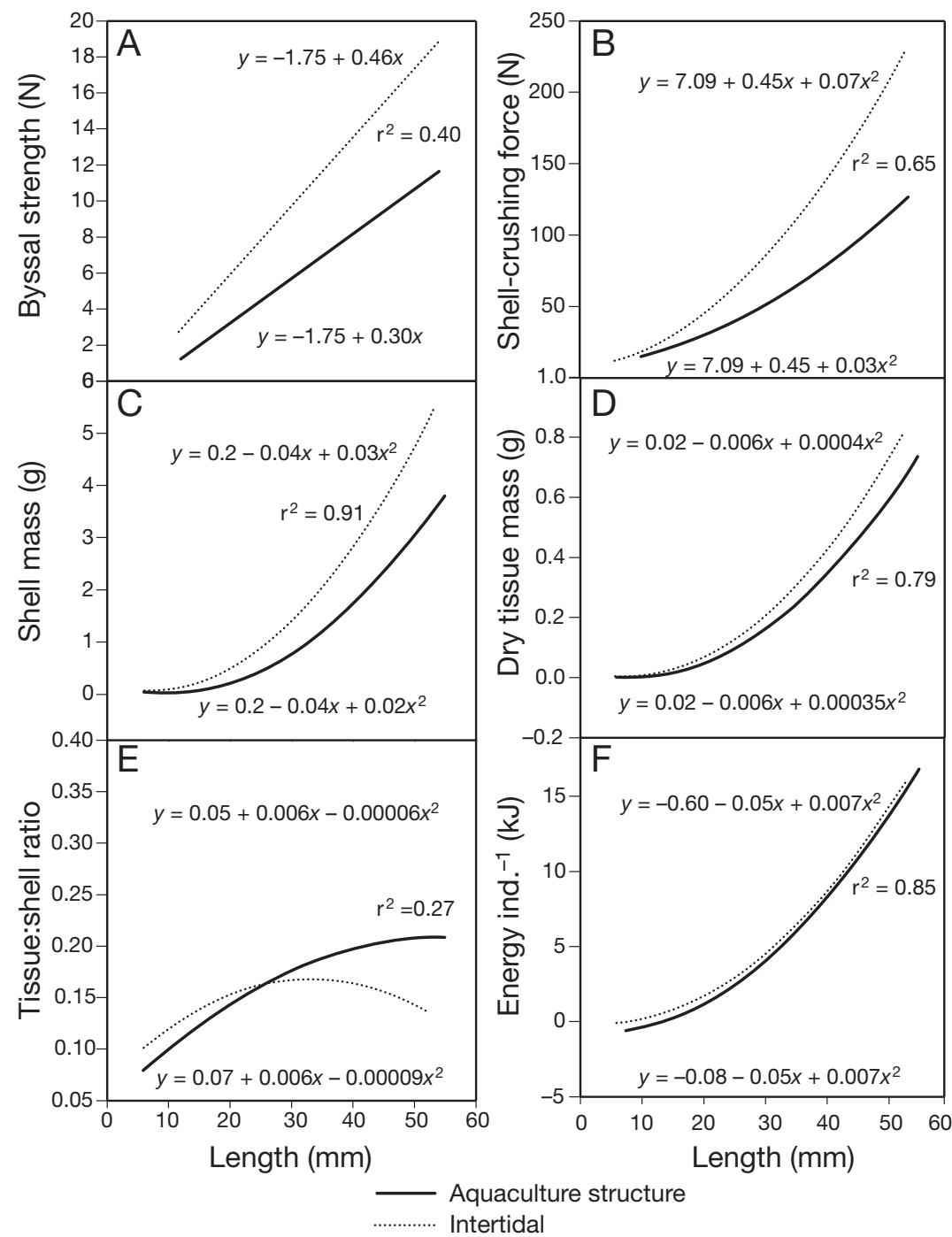

Fig. 3. Mytilus sp. Mussel characteristics by length and habitat in Malaspina Inlet, British Columbia, 2004-2005. (A) Byssal strength, (B) shell-crushing force, (C) shell mass, (D) shell-free dry mass, (E) tissue to shell ratio, (F) total energy per individual. Models, lines, and $\mathrm{r}^{2}$ values (which apply to both lines) are from the most parsimonious general linear model

model explaining variation in shell mass included length, length squared, and a length squaredhabitat interaction $\left(\mathrm{AIC}_{\mathrm{c}} \mathrm{W}=0.56, \mathrm{r}^{2}=0.92\right)$. However, a second model received similar support $\left(\mathrm{AIC}_{\mathrm{C}} \mathrm{W}=\right.$ $0.44, r^{2}=0.92$ ) and included a main effect of habitat, which indicates an even greater shell mass for intertidal mussels as compared to farm habitats. Under both models, shell mass increased with length, and intertidal mussels tended to have heavier shells for a given length (Fig. 3C).

Shell-free dry mass, the flesh content of mussels, also increased exponentially with length (Fig. 3D). Intertidal mussels showed a slightly stronger increase in dry tissue mass, resulting in the largest length classes having greater tissue mass than mussels at farms. The model best supported by the data (Table 2) included a habitat-length squared interaction $\left(\mathrm{AIC}_{\mathrm{C}} \mathrm{W}=0.85, \mathrm{r}^{2}=\right.$ 0.79 ). The model that best explained tissue to shell ratio variation was the length and habitat model with a length squared-habitat interaction $\left(\mathrm{AIC}_{\mathrm{C}} \mathrm{W}=\right.$ $0.85, \mathrm{r}^{2}=0.27$, Table 2). In both habitats, the ratio increased until about the $25 \mathrm{~mm}$ length class, indicating that tissue mass is gained more quickly than shell mass (Fig. 3E). After $25 \mathrm{~mm}$, the intertidal mussel tissue-shell ratio declined indicating that more mass was invested in shell than tissue. The ratio of tissue to shell of farm mussels continued to increase after $25 \mathrm{~mm}$ but at a slower rate.

Energy density of mussels $\left(\mathrm{kJ} \mathrm{g}^{-1}\right)$ did not vary by length or habitat. Average energy $\mathrm{g}^{-1}$ dry tissue was $19.9 \mathrm{~kJ}$ $( \pm 0.1 \mathrm{SE})$, and the null model received strongest support $\left(\mathrm{AIC}_{\mathrm{C}} \mathrm{W}=0.48\right.$, Table 2 ). The second and third ranked models suggest that energy density increased very marginally with length (0.01 to $\left.0.08 \mathrm{~kJ} \mathrm{~mm}^{-1}\right)\left(\mathrm{AIC}_{\mathrm{C}} \mathrm{W}=0.19\right.$ or 0.16 , Table 2). Both length and habitat were important in explaining energy per individual mussel. The length and habitat model was ranked as most parsimonious $\left(\mathrm{AIC}_{\mathrm{c}} \mathrm{W}=0.44, \mathrm{r}^{2}=0.85\right.$, Table 2 ), while the length model and the length, habitat, length-squared-habitat interaction model both received moderate support (both $\mathrm{AIC}_{\mathrm{C}} \mathrm{W}=0.26$ ). In each of the 3 best-supported models, energy of mussels increased exponentially with length, and intertidal mussels had slightly higher energy content, due to higher tissue mass (Fig. 3F).

\section{DISCUSSION}

We found that mussel density and morphology differed dramatically between shellfish aquaculture structures and intertidal habitats, in ways that would be expected to affect foraging of molluscivorous sea ducks. Mussel densities were considerably higher on farms than in intertidal habitats in the fall. Also, mussels on farms tended to be larger, thinner-shelled, and attached more weakly to the growing substrate. Although farmed mussels had slightly less tissue mass for a given length than intertidal mussels, farmed mus- 
sel tissue to shell ratios were higher in the length classes above $25 \mathrm{~mm}$. As in previous studies, we found that epibiotic assemblages that grow on artificial floating structures are different from those on nearby shorelines (Connell 2001, Smith \& Rule 2002). Mytilus spp. densities have been shown to be higher on artificial floating structures (Connell 2001, Glasby \& Connell 2001, Holloway \& Connell 2002), a pattern also confirmed in the present study but one that had never been addressed specifically for shellfish aquaculture operations. In terms of trophic consequences resulting from epibiota recruited on artificial structures, our results indicate that some major mussel predators, namely sea ducks, likely benefit from the introduction of shellfish aquaculture structures, through increases in both density and the resulting profitability attributes of their mussel prey.

Several mechanisms may contribute to higher densities of mussels on shellfish aquaculture structures. Larval settlement may be enhanced on structures if planktonic pediveligers are preferentially selecting them as settlement locations. In contrast to intertidal sites, shellfish aquaculture structures are always submerged, increasing their exposure to potential settlers. Higher settlement might be induced by higher water flow, movement and swash on farm structures floating on the surface of the water (Glasby \& Connell 2001). In addition, depth-stratification of larvae (i.e. when larvae have an uneven distribution in the water column or show some behavioural selection of depth; Grosberg 1985), might promote settlement on farms. There are reports of Mytilus sp. larvae concentrating at the surface (Fuentes \& Molares 1994), in the same depth zone as aquaculture rafts.

Shellfish aquaculture structures might also act as refugia from sea stars, crabs or other invertebrate predators that cannot access suspended lines or buoys. It is well established that the foraging activities of the keystone predator Pisaster spp. sea star control intertidal adult distributions of mussels (Menge et al. 1994). In Malaspina Inlet, we observed high numbers of Pisaster ochraceous at all intertidal locations surveyed, but very few on any farm structures or lines. Shore crabs Hemigrapsus oregonensis and $H$. nudus were present in the intertidal sites but probably only consume the smallest length classes of mussels. Red-rock crabs Cancer productus are a more likely predator of larger mussels, but this species is generally subtidal and were never observed in any intertidal sites. Only one crab species, the herbivorous kelp crab Pugettia producta, was observed on aquaculture structures. If the spring mussel set recruited equally onto aquaculture structures and intertidal reefs, high predation in the intertidal habitat and little or no predation on farms, could lead to the observed disparity in fall mus- sel densities. P. ochraceous sea stars, as large-bodied and abundant predators primarily active in the summer months, could easily impact intertidal populations of juvenile mussels (Robles et al. 1995). On farms that were inaccessible to sea stars and predatory crabs, mussels could persist in the observed higher numbers until fall when sea ducks return to Malaspina Inlet.

Mussels on shellfish aquaculture structures were not only denser but also had less developed anti-predator attributes than those in intertidal habitats. Byssal thread attachments were weaker for individuals growing on farm structures. This may have been due to differences in exposure to wind and wave activity, the strongest predictor of byssal attachment strength (Harger 1970, Hunt \& Scheibling 2001). Despite the protected nature of Malaspina Inlet, winter storms are common and tidal fluctuations and wind likely generated strong shear forces on intertidal mussels. Disturbance forces within the purely subtidal waters of the shellfish aquaculture farms would be lower, reducing the 'farm' mussel's need for strong byssal attachment. Also, under high predation regimes, Mytilus edulis produced more and stronger byssal threads to prevent dislodgement by crab or sea star predators (Leonard et al. 1999, Reimer \& HarmsRingdahl 2001). Invertebrate predators were largely absent from shellfish aquaculture structures, so this also may have influenced byssal strength.

At the shellfish aquaculture farms, mussel shells were less massive and had a lower shell-crushing resistance compared to intertidal mussels. Intertidal mussels likely produce a thicker shell in response to exposures stresses and wave activity (Seed 1968, Beadman et al. 2003), while the fast-growing subtidal mussels (Seed 1968) and mussels at high densities (Alumno-Bruscia et al. 2001) tend to have less massive shells. Shell morphology is also considered to be an inducible plastic defense. Shell thickening and strengthening was observed in mussels where predation by crabs or cues from crab predators increased (Leonard et al. 1999, Reimer \& Harms-Ringdahl 2001). Sea stars can induce thicker shells, larger adductor muscles and reduced linear growth in their mussel prey (Reimer \& Tedengren 1996, Reimer \& HarmsRingdahl 2001). Mussels on farms were longer, suggesting they may increase growth rather than invest in development of defensive morphology. We suspect that shellfish aquaculture structures in Malaspina Inlet are a refuge from sea star and crab predators during the high mussel growth period of summer, which may have also contributed to observed morphological differences in the fall.

The differences in density and morphology of mussels between intertidal habitats and shellfish aquaculture structures have important implications for their 
primary winter predators, sea ducks. First, the high densities of mussels growing close to the surface on shellfish aquaculture structures would eliminate search time for a foraging duck. Also, mussels on shellfish aquaculture structures grew faster, and thus achieved more profitable sizes. Weaker byssal thread attachment of 'farm' mussels reduce the duck's investment in prey item capture; increased byssal strength is linked to reduced intake rates in diving ducks (De Leeuw 1999). Shell-crushing resistance is an important energetic cost to ducks, including surf scoters and Barrow's goldeneyes, that crush bivalve prey with their gizzards (Hamilton et al. 1999, Richman \& Lovvorn 2003), and they will selectively minimize the amount of shell ingested (Bustnes \& Erikstad 1990). Mussels on farm structures had less massive shells and required less force to crush, suggesting another energetic advantage for sea ducks.

We have demonstrated that shellfish aquaculture structures support a population of mussels that is both denser and more profitable for molluscivorous sea ducks than intertidal mussels. We have several lines of evidence that sea ducks responded to differences in prey in predictable ways. First, mussels on shellfish aquaculture structures were strongly depleted during the period of sea duck occupancy of the study area (Fig. 1), indicating that sea ducks consumed (or dislodged) almost all available mussels in that habitat. Mussels in intertidal habitats also were depleted, but not nearly to the extent of those on shellfish aquaculture structures, suggesting that predation pressure was higher on farms over the winter. Also, surf scoters and Barrow's goldeneyes showed strong preferences for areas with shellfish aquaculture farms, based on a habitat use analysis of survey data (R. Žydelis, Simon Fraser University, unpubl. data). Similarly, radiomarked surf scoters in Malaspina Inlet clearly favoured foraging in shellfish farm habitats (Kirk 2007), particularly in early winter before heavy mussel depletion occurred, presumably in response to the abundant and profitable prey. Flocks of foraging sea ducks rapidly depleted mussel growth locally, suggesting that ducks have a strong impact on mussel density. However, due to the timescale over which these predation events occurred (sometimes a matter of days), it is unlikely that the ducks induced defensive shell morphology in farm habitats. The spring sampling indicated that the mussels remaining on farms were too large to be consumed by sea ducks. In the intertidal area, mussel beds experienced sea duck predation consistently over several months and ducks, along with invertebrate predators, may have exerted selective pressure on mussel morphology. To test this hypothesis, sea ducks could be excluded from parts of farm and intertidal sites, and mussel morphological traits compared to open plots.
We conclude that introduced aquaculture structures supporting unique epibiotic communities constitute a positive outcome for molluscivorous sea ducks. Surf scoters distribution was positively correlated with the presence of aquaculture structures (R. Žydelis, Simon Fraser University, unpubl. data) as ducks responded to the abundant and profitable mussel prey. Foraging effort of surf scoters at these farms was reduced in early winter when prey density was high, and similar to other habitats through the rest of the season (Kirk 2007). Lastly, survival of scoters was not related to the presence or use of shellfish aquaculture habitats. We considered implications only for sea ducks, and encourage further work that would evaluate the effects of artificial structures and shellfish farms on other components of the ecosystem. Floating structures associated with mariculture can alter the composition and quality of benthic sediments and change associated infaunal communities (Stenton-Dozey et al. 2001). Also, aquaculture often entails artificially introducing and enhancing exotic species, which may impact populations of native fauna.

These results are particularly encouraging, as many anthropogenic changes to coastal habitats have negative consequences for natural communities. Other types of artificial structures would presumably show a similar beneficial relationship with foraging sea ducks, assuming that mussel growth is enhanced. Because mussel recruitment and growth vary annually, the degree of the positive effects of artificial structures on sea ducks likely also vary. Sea ducks in many coastal areas are often associated with structures such as wharfs and jetties, possibly because of the mechanisms described in this study. Birds, and waterfowl in particular, are well known to respond to changes in prey including the introduction of novel species, or increased abundance due to anthropogenic activity (Dionne 2004). As an additional note of encouragement, shellfish farmers in Malaspina Inlet welcome sea duck foraging in their farms. Unlike situations in which diving ducks are consuming cultured bivalves (Dionne 2004) and are considered a nuisance, sea ducks in Malaspina Inlet serve to clean the oyster culture structures, which the farmers would otherwise have to do themselves, a practice that is both labour and time intensive. Cooperative management of aquaculture activities will ensure the sustainability of this unique and mutually beneficial relationship that currently exists between sea ducks and shellfish farmers.

Acknowledgements. The Canadian Wildlife Service of Environment Canada, a National Science and Engineering Research Council (NSERC) strategic grant STPGP246079-01 and the Institute for Wetland and Waterfowl Research of Ducks Unlimited Canada funded this study. We also thank the Centre for Wildlife Ecology, Simon Fraser University, for 
providing laboratory access, and scientific and logistic support. The following people provided field or lab assistance: B. Bartzen, K. Gorman, D. Lacroix, H. Rahmani and P. Ridings. We also thank all shellfish farmers within Malaspina Inlet who granted us access to their leases.

\section{LITERATURE CITED}

Akester RJ, Martel AL (2000) Shell shape, dysodont tooth morphology, and hinge-ligament thickness in the bay mussel Mytilus trossulus correlate with wave exposure. Can J Zool 78:240-253

Alumno-Bruscia M, Bourget E, Fréchette M (2001) Shell allometry and length-mass-density relationship for Mytilus edulis in an experimental food-regulated situation. Mar Ecol Prog Ser 219:177-188

Beadman HA, Caldow RWG, Kaiser MJ, Willows RI (2003) How to toughen up your mussels: using shell morphological plasticity to reduce predation losses. Mar Biol 142:487-494

Burnham KP, Anderson DR (2002) Model selection and inference: a practical information-theoretic approach. SpringerVerlag, New York

Bustnes JO, Erikstad KE (1990) Size selection of common mussels, Mytilus edulis, by common eiders, Somateria mollissima: energy maximization or shell weight minimization? Can J Zool 68:2280-2283

Connell SD (2001) Urban structures as marine habitats: an experimental comparison of the composition and abundance of subtidal epibiota among pilings, pontoons and rocky reefs. Mar Environ Res 52:115-125

De Leeuw JJ (1999) Food intake rates and habitat segregation of tufted duck Aythya fuligula and scaup Aythya marila exploiting zebra mussels Dreissena polymorpha. Ardea 87: 15-31

Dionne M (2004) Relationship between diving ducks and mussel aquaculture in Prince Edward Island, Canada. MSc Thesis, University of New Brunswick, Fredriction, NB

Fuentes J, Molares J (1994) Settlement of the mussel Mytilus galloprovincialis on collectors suspended from rafts in the Ria de Arousa (NW of Spain): annual pattern and spatial variability. Aquaculture 122:55-62

Glasby TM, Connell SD (1999) Urban structures as marine habitats. Ambio 28:595-598

Glasby TM, Connell SD (2001) Orientation and position of substrata have large effects on epibiotic assemblages. Mar Ecol Prog Ser 214:127-135

Goss-Custard JD, West AD, Le V Dit Durell SEA (1993) The availability and quality of the mussel prey (Mytilus edulis) of oystercatchers (Haematopus ostralegus). Neth J Sea Res 31:419-439

Grosberg RK (1985) Intertidal zonation of barnacles: the influence of larvae on vertical distribution of adults. Ecology 63: 894-899

Guillemette M, Reed A, Himmelman JH (1996) Availability and consumption of food by common eiders wintering in the Gulf of St. Lawrence: evidence of prey depletion. Can J Zool 74:32-28

Hamilton DJ, Nudds TD, Neate J (1999) Size-selective predation of blue mussels (Mytilus edulis) by common eiders (Somateria mollissima) under controlled field conditions. Auk 116:403-416

Harger JR (1970) The effect of wave impact on some aspects of biology of sea mussels. Veliger 12:401-414

Holloway MG, Connell SD (2002) Why do floating structures create novel habitats for subtidal epibiota? Mar Ecol Prog Ser 235:43-52

Editorial responsibility: Charles Peterson (Contributing Editor), Morehead City, North Carolina, USA
Hunt HL, Scheibling RE (2001) Predicting wave dislodgment of mussels: variation in attachment strength with body size, habitat, and season. Mar Ecol Prog Ser 213:157-164

Kirk M (2007) Movement and foraging behaviours of surf scoters wintering in aquaculture-modified habitats. MSc Thesis, Simon Fraser University, Burnaby, BC

Larsen JK, Guillemette M (2000) Influence of annual variation in food supply on abundance of wintering common eiders Somateria mollissima. Mar Ecol Prog Ser 201:301-309

Lasiak TA, Underwood AJ, Hoskin M (2006) An experimental assessment of the potential impacts of longline mussel farming on the infauna in an open coastal embayment. Aquat Conserv Mar Freshw Ecosys 16:289-300

Leonard GH, Bertness MD, Yund PO (1999) Crab predation, waterborne cues and inducible defenses in the blue mussel, Mytilus edulis. Ecology 80:1-14

Lewis TL, Esler D, Boyd WS (2007) Effects of predation by sea ducks on clam abundance in soft-bottom intertidal habitats. Mar Ecol Prog Ser 329:131-144

McDonald JH, Seed R, Koehn RK (1991) Allozymes and morphometric characters of three species of Mytilus in the Northern and Southern hemispheres. Mar Biol 111:323-335

Menge BA, Berlow EL, Blanchette SA, Navarette SA, Yamada SB (1994) The keystone species concept: variation in interaction strength in a rocky intertidal habitat. Ecol Monogr 64:249-286

Norberg J, Tedengren M (1995) Attack behaviour and predatory success of Asterias rubens L. related to differences in size and morphology of the prey mussel Mytilus edulis L. J Exp Mar Biol Ecol 186:207-220

Reimer O, Harms-Ringdahl S (2001) Predator-inducible changes in blue mussels from the predator-free Baltic Sea. Mar Biol 139:959-965

Reimer O, Tedengren M (1996) Phenotypical improvement of morphological defences in the mussel Mytilus edulis induce by exposure to the predator Asterias rubens. Oikos 75: 383-390

Richman SE, Lovvorn JR (2003) Effects of clam species dominance on nutrient and energy acquisition by spectacled eiders in the Bering Sea. Mar Ecol Prog Ser 261:283-297

Robles C, Sherwood-Stephens R, Alvarado M (1995) Responses of key intertidal predator to varying recruitment of its prey. Ecology 76:565-579

Seed R (1968) Factors influencing shell shape in mussel Mytilus Edulis. J Mar Biol Assoc UK 48:561-584

Seed R, Suchanek TH (1992) Population and community ecology of Mytilus. In: Gosling E (ed) The mussel Mytilus: ecology, physiology, genetics and culture. Elsevier, New York, p 599

Smith SDA, Rule MJ (2002) Artificial substrata in a shallow sublittoral habitat: Do they adequately represent natural habitats or the local species pool? J Exp Mar Biol Ecol 277 : $25-41$

Stenton-Dozey J, Probyn T, Busby A (2001) Impact of mussel (Mytilus galloprovincialis) raft-culture on benthic macrofauna, in situ oxygen uptake and nutrient fluxes in Saldanha Bay, South Africa. Can J Fish Aquat Sci 58: 1021-1031

Suchanek TH, Geller JB, Kreiser BR, Mitton JB (1997) Zoogeographic distributions of sibling species Mytilus galloprovincialis and $M$. trossulus (Bivalvia: Mytilidae) and their hybrids in the North Pacific. Biol Bull 193: 187-194

Žydelis R, Esler D, Boyd S, Lacroix DL, Kirk M (2006) Habitat use by wintering surf and white-winged scoters: effects of environmental attributes and shellfish aquaculture. J Wildl Manag 70:1754-1762

Submitted: February 20, 2007; Accepted: May 10, 2007

Proofs received from author(s): September 17, 2007 